Received Date : 21-Oct-2016

Revised Date : 28-Nov-2016

Accepted Date : 10-Dec-2016

Article type : Short Communication

Editor: James Pearce-Higgins

\title{
Effects of spring temperature and volcanic eruptions on wader productivity
}

Tómas Grétar Gunnarsson ${ }^{1}{ }^{*}$, Lilja Jóhannesdóttir ${ }^{1}$, José A. Alves ${ }^{1,2}$, Böđvar Pórisson ${ }^{1}$ \& Jennifer A. Gill ${ }^{3}$

${ }^{1}$ University of Iceland, South Iceland Research Centre, Fjölheimar, Bankavegur, IS-800 Iceland \& Gunnarsholt, IS-851 Hella, Iceland

${ }^{2}$ DBIO \& CESAM - Centre for Environmental and Marine Studies, University of Aveiro, 3800 Aveiro, Portugal

${ }^{3}$ School of Biological Sciences, University of East Anglia, Norwich Research Park, Norwich NR4 7TJ, UK

* Corresponding author.

Email: tomas@hi.is

Key demographic parameters often show substantial annual variation that can have important consequences for rates of population growth. Since 2011 we have conducted annual estimates of the productivity of Icelandic Black-tailed Godwits Limosa limosa islandica over a large part of its breeding range. During this period, a volcanic eruption resulted in extensive dust deposition across the region. We show that Godwit productivity varies with spring temperatures but, in the year of the volcanic eruption, productivity was reduced to almost zero. This rare but extreme event is likely to

This article has been accepted for publication and undergone full peer review but has not been through the copyediting, typesetting, pagination and proofreading process, which may lead to differences between this version and the Version of Record. Please cite this article as doi: 10.1111/ibi. 12449

This article is protected by copyright. All rights reserved. 
have had only a short-term influence, while ongoing warming of subarctic regions is potentially a more substantial driver of the continued growth of this population.

A major driver of population growth rates is the temporal variation in recruitment (Sæther et al. 2016). However, identifying temporal drivers of demography may require information collected over sufficiently large spatial scales to encompass the influence of variation in local factors such as habitat quality, density and predation rates, which can also influence demography (Jónsson et al. 2013, Stojanovic et al. 2014). In order to develop the population-wide demographic models needed in a rapidly changing world (Robinson et al. 2014), long-term, large-scale studies of temporal variation in demography are therefore needed. In particular, extreme but rare events may have important effects on demography, but are inevitably difficult to identify (Katrínardóttir et al. 2015, Senner et al. 2015).

Many populations of waders (Charadrii) breed in temperate or Arctic regions, undertake long migrations to their wintering grounds, and currently have declining global populations (Thomas et al. 2007, Delany et al. 2009, Sutherland et al. 2012). It is therefore necessary to identify drivers of variation in demographic rates of waders in order to manage their impacts. Migratory wader populations, particularly those breeding in Arctic latitudes, often show high levels of annual variation in productivity over large spatial scales. For example, the proportion of juveniles in flocks of high Arctic-nesting species on the non-breeding grounds has been shown to fluctuate annually, in association with population abundance cycles of lemmings (Lemmus spp., Dicrostonyx spp. ) in the Arctic (Summers \& Underhill 1987, Aharon-Rotman et al. 2015), and the proportion of juveniles in non-breeding wader flocks has also been shown to vary annually with weather conditions during the breeding season (Schekkerman et al. 1998, Beale et al. 2006).

Iceland hosts internationally important breeding populations of several wader species (Gunnarsson et al. 2006), including almost the entire population of the islandica subspecies of Black-tailed Godwit Limosa limosa islandica (Gunnarsson et al. 2005a). Godwits are restricted to breeding in lowland basins around the country, with the southern lowlands of Iceland containing the largest breeding area and hosting around half of the breeding population (Gunnarsson et al. 2006, Jóhannesdóttir et al. 2014). In 2011, a monitoring programme was initiated for Godwits (and for more species from 2012), in which brood counts are used to estimate annual variation in breeding success in the southern lowlands. In 2010 and 2011, two volcanoes erupted in Southern Iceland; Eyjafjallajökull

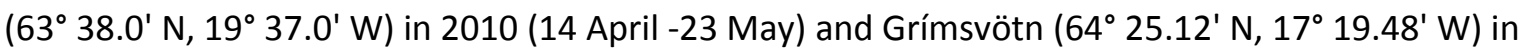
2011 (21-28 May) (Sigmundsson et al. 2010, Petersen et al. 2012). Both these eruptions emitted

This article is protected by copyright. All rights reserved. 
large amounts of volcanic dust and, while much of the ash from Eyjafjallajökull went out to sea, Grimsvotn ash was widely distributed in southern Iceland (Gudmundsson et al. 2012). During the field season of 2011, volcanic ash was widespread in the study area but its daily prevalance was highly dependent on local weather conditions. On dry days, fieldworkers used face masks to protect their respiration as simply walking through vegetation disturbed large amounts of ash into the air. The ash was further redistributed by wind and often formed piles in depressions. A layer of ash was frequently observed covering pools in wetlands and traps for invertebrate sampling frequently became clogged with ash. Short-term negative effects of volcanic dust on birds have been reported previously, and are probably mediated through increased invertebrate mortality (Dalsgaard et al. 2007, Marske et al. 2007). For example, a pronounced reduction in breeding success of Icelandic Whimbrels Numenius phaeopus breeding closer to the eruption site was recorded in 2011 (Katrínardóttir et al. 2015). However, the duration of impact of the eruption on breeding waders and the spatial scale over which these effects may be apparent are unknown, as the opportunities to explore the effects of volcanic eruptions on bird demography are exceedingly rare. At high latitudes, timing of breeding and breeding success can also vary in relation to spring temperatures, probably as a consequence of temperature-driven variation in vegetation growth and invertebrate emergence and abundance (Tulp \& Schekkerman 2008, Alves et al. in prep). The volcanic activity that coincided with our monitoring programme provided a unique opportunity to explore both the effects of spring temperature and of stochastic extreme events on large-scale productivity of a wader population on the sub-arctic breeding grounds. Here we quantify annual variation in Godwit productivity in order to assess whether productivity increases with spring temperatures but is negatively impacted by volcanic eruptions, and to assess the magnitude and duration of any effects of volcanic activity.

\section{METHODS}

\section{Estimating large-scale productivity}

During the last ten days of June 2011-2016, road-based surveys were carried out over a large part of the lowlands of southern Iceland (Fig. 1). The car was driven at a maximum speed of $40 \mathrm{~km} / \mathrm{hr}$, with open windows. Surveying was only conducted in dry conditions and at windspeeds below $7 \mathrm{~m} / \mathrm{s}$. Along transects which totalled $198 \mathrm{~km}$ (Figure. 1), the presence of all alarming adult Godwits within $100 \mathrm{~m}$ of the car was recorded. All habitats along the transect were surveyed irrespective of their suitability for Godwits. Godwits (and many other waders) perform noisy and conspicuous alarm behaviour near their chicks (Gunnarsson et al. 2005b) and previous studies have shown that strongly

This article is protected by copyright. All rights reserved. 
alarming adults are a robust indicator of the presence of one or more chicks (Gunnarsson et al. 2005b). Each strongly alarming individual or pair was taken as presence of a brood. In each case the perpendicular distance from the road transect to the chicks (when seen) was recorded with a laser range finder to ensure only chicks within $100 \mathrm{~m}$ of the road were included, along with a GPS position of the car on the road. In those cases when chicks were not observed, the distance to the alarming adult or, for pairs, the midpoint between the two adults was recorded. The number of broods recorded along the transect was used as an estimate of annual productivity. The conspicuous alarming behaviour of adults means that detectability of broods is very unlikely to vary within $100 \mathrm{~m}$ of the vehicle.

\section{Weather data}

To assess the influence of spring temperature on large-scale productivity, we extracted the mean daily temperature during May of each year (2011-2016) from the weather station of the Icelandic Meteorological Institute (www.vedur.is) nearest to the transect (Eyrarbakki $63^{\circ} 52^{\prime} \mathrm{N}, 21^{\circ} 09^{\prime} \mathrm{W}$ ). The relationship between spring temperature (mean May temperature) and annual Godwit productivity was assessed using a GLM with a normal error structure, with and without the year in which the volcanic eruption took place (2011).

\section{Timing of laying}

As part of long-term studies of Godwit breeding ecology in southern Iceland, the timing of egg laying has been monitored each year since 2001 (Alves et al. in prep) by locating as many nests as possible and floating the eggs to hindcast the date of laying of the first egg (Liebezeit et al. 2007). In each year of 2011-2016, between 14 and 28 Godwit nests (mean = 20.6 \pm 5.5 SD) were monitored in the southern lowlands. As the surveys all took place in late June, the number of broods observed in each year could be influenced by the timing of egg laying. To assess whether our annual estimates of productivity varied in relation to timing of egg laying, a GLM with annual productivity as the dependent variable and mean nest initiation date as the predictor and a normal error structure was used.

Statistics were performed in R 3.2.2 (R Development Core Team 2008).

This article is protected by copyright. All rights reserved. 


\section{RESULTS}

The mean number of broods recorded within $100 \mathrm{~m}$ along the 198-km transect between 2011 and 2016 was 17.8 ( \pm 10.1 SD) but the variation between years was extremely high (range 2-31 broods per year; Fig. 2a).

The number of broods along the transect was strongly, positively related to mean May temperature in each year between 2012 and 2016 but not when 2011 was included (Fig. 2b). In 2011, when the region was largely covered by volcanic ash, only 2 broods were recorded along the transect. This number of broods is only $7.5 \%$ of the value ( 26.7 broods) that would be predicted by the relationship with mean May temperature for non-eruption years $\left(7.2^{\circ} \mathrm{C}\right.$, the second highest May temperature in 2011-2016) (Fig. 2b).

The overall mean start of laying in 2011-2016 was 26 May (range 21-28 May), and the mean timing of nest initiation in each year was not significantly related to the number of broods present in late June $\left(R^{2}=0.399, P=0.18\right)$.

\section{DISCUSSION}

During a six-year period in which spring temperatures varied greatly and a major volcanic eruption took place in southern Iceland, we recorded substantial variation in the productivity of Godwits. The variation in productivity between 2012 and 2016 was very closely and positively related to mean May temperatures. However, during a relatively warm spring (2011) when a volcanic eruption impacted the study area, productivity of the Godwit population fell to almost nothing. The study provides a rare example of the magnitude of impact that extreme events such as a volcanic eruption may possibly have on bird productivity but also highlights the likely short-term duration of such an event. Godwits are long-lived (median lifespan c. 10 years; Gill et al. 2001) and events of this type are rare in comparison to their typical lifespan. A large part of the Icelandic Godwit population winters on the estuaries of Britain, and annual censuses on these areas have shown sustained increases in the Godwit population (Frost et al. 2016). Intriguingly, the population index for 2011/12 (immediately following the eruption) decreased slightly before increasing quite substantially the following winter (Frost et al. 2016), potentially reflecting the reduction and subsequent increase in productivity recorded in our surveys on the breeding grounds.

This article is protected by copyright. All rights reserved. 
The rapid recovery of productivity in the year following the volcanic eruption (2012) indicates that the negative effects of the volcanic eruption seem to be short in duration. A similar effect has been observed in Whimbrels in the same region where large-scale breeding success was temporarily negatively impacted during the 2011 eruption (Katrínardóttir et al. 2015). In the long-term, the effects of volcanism on waders in Iceland are most likely to be positive, as volcanic dust recharges vegetated land with nutrients, buffers $\mathrm{pH}$, and densities of waders across Iceland are generally higher where volcanic dust inputs are higher (Gunnarsson et al. 2015). The negative short-term effects of volcanic eruptions are likely to be due to the effects of the high volume of volcanic dust on invertebrate prey populations. Previous studies have suggested that the brittle volcanic dust can cause mortality of invertebrates through blocking of the spiracles and increased rates of abrasion and desiccation (Marske et al. 2007, Elizalde 2015). Volcanic eruptions may also influence water and air quality (Horwell \& Baxter 2006, Stewart et al. 2006), and the presence of large amounts of ash covering the ground could encourage adults to defer breeding attempts in that year.

The process by which higher spring temperatures promote higher productivity is not yet fully understood but is likely to be a combination of factors. It is worth noting that even though May and June temperatures were not correlated for the set of years considered here, temperature in these months is correlated in longer time series (Alves et al. in prep.) so temperature links with productivity may well operate over longer or different periods than for the May correlate explored here. The timing of emergence of the invertebrate prey of waders can vary strongly with temperature (Tulp \& Schekkerman 2008, Pearce-Higgins et al. 2010), and the resulting variation in food abundance can potentially affect both adult body condition and the growth and survival of young (Schekkerman et al. 1998a, Pearce-Higgins et al. 2010). The timing of laying of Godwits in Iceland is earlier in warmer springs (Gill et al. 2014, Alves et al. in prep) and thus variation in the number of broods counted in late June could result from differences in hatch dates (with fewer broods having hatched by late June in colder years). However, the annual variation in productivity that we recorded was unrelated to timing of laying in these years. Another potential driver of a relationship between spring weather and productivity in waders is the proportion of adults which defer breeding attempts or do not renest upon early failure each year but this may be more common in colder springs when adults are in poorer body condition. Our relationship with prebreeding tempearature (May) may point to the potential of this process to influence large-scale productivity. However, little is known about how common deferral of breeding may be in these species.

This article is protected by copyright. All rights reserved. 
This study shows how annual variation in productivity of a wild bird population over large areas can vary greatly in response to both rare, extreme events and moderate but persistent effects of temperature on environmental conditions. As expected for a long lived species, effects of a single year of very low productivity were short in duration and probably had a limited effect on population growth rate. The pronounced effect that spring temperature has on annual variation in productivity is, however, likely to be crucial for the future population trajectory of Godwits and related species, given the ongoing and rapid warming of Arctic and Sub-arctic regions.

This work was supported by Icelandic Research Council (Rannís) Grant of Excellence number 130412051, NERC Grant number NE/M012549/1 and FCT grant SFRH/BPD/91527/2012. We thank Daniel Ruthrauff and James Pearce-Higgins for suggesting very helpful changes to the manuscript.

\section{References}

Aharon-Rotman, Y., M. Soloviev, C. Minton, P. Tomkovich, C. Hassell, and M. Klaassen. 2015. Loss of periodicity in breeding success of waders links to changes in lemming cycles in Arctic ecosystems. Oikos 124:861-870.

Alves, J. A., T. G. Gunnarsson, W. J. Sutherland, P. M. Potts, and J. A. Gill. in prep. Linking warming effects on phenology and demography with range expansion in a migratory bird population.

Beale, C. M., S. Dodd, and J. W. Pearce-Higgins. 2006. Wader recruitment indices suggest nesting success is temperature-dependent in Dunlin Calidris alpina. Ibis 148:405-410.

Dalsgaard, B., G. Hilton, G. Gray, L. Aymer, J. Boatswain, J. Daley, C. Fenton, J. Martin, L. Martin, and P. Murrain. 2007. Impacts of a volcanic eruption on the forest bird community of Montserrat, Lesser Antilles. Ibis 149:298-312.

Delany, S., D. Scott, T. Dodman, and D. Stroud. 2009. An atlas of wader populations in Africa and Western Eurasia. British Birds 102:639-642.

Elizalde, L. 2015. Volcanism and arthropods: a review. Ecología austral 24:3-16.

Frost, T. M., G. M. Austin, N. A. Calbrade, C. Holt, H. J. Mellan, R. D. Hearn, D. A. Stroud, S. R. Wotton, and D. E. Balmer. 2016. Waterbirds in the UK 2014/15: The Wetland Bird Survey. BTO, RSPB and JNCC, in association with WWT. British Trust for Ornithology, Thetford.

Gill, J. A., J. A. Alves, W. J. Sutherland, G. F. Appleton, P. M. Potts, and T. G. Gunnarsson. 2014. Why is timing of bird migration advancing when individuals are not? Proceedings of the Royal Society of London B: Biological Sciences 281:20132161.

Gill, J. A., K. Norris, P. M. Potts, T. G. Gunnarsson, P. W. Atkinson, and W. J. Sutherland. 2001. The buffer effect and large-scale population regulation in migratory birds. Nature 412:436-438.

Gudmundsson, M. T., T. Thordarson, Á. Höskuldsson, G. Larsen, H. Björnsson, F. J. Prata, B. Oddsson, E. Magnússon, T. Högnadóttir, and G. N. Petersen. 2012. Ash generation and distribution from the April-May 2010 eruption of Eyjafjallajökull, Iceland. Scientific reports 2:572.

Gunnarsson, T. G., Ó. Arnalds, G. Appleton, V. Méndez, and J. A. Gill. 2015. Ecosystem recharge by volcanic dust drives broad-scale variation in bird abundance. Ecology and evolution 5:23862396.

Gunnarsson, T. G., J. A. Gill, G. F. Appleton, H. Gíslason, A. Gardarsson, A. R. Watkinson, and W. J. Sutherland. 2006. Large-scale habitat associations of birds in lowland Iceland: implications for conservation. Biological Conservation 128:265-275.

This article is protected by copyright. All rights reserved. 
Gunnarsson, T. G., J. A. Gill, P. M. Potts, P. W. Atkinson, R. E. Croger, G. Gélinaud, A. Gardarsson, and W. J. Sutherland. 2005a. Estimating population size in Black-tailed Godwits Limosa limosa islandica by colour-marking. Bird Study 52:153-158.

Gunnarsson, T. G., J. A. Gill, A. Petersen, G. Appleton, and W. J. Sutherland. 2005b. A double buffer effect in a migratory shorebird population. Journal of Animal Ecology 74:965-971.

Horwell, C. J., and P. J. Baxter. 2006. The respiratory health hazards of volcanic ash: a review for volcanic risk mitigation. Bulletin of Volcanology 69:1-24.

Jóhannesdóttir, L., Ó. Arnalds, S. Brink, and T. G. Gunnarsson. 2014. Identifying important bird habitats in a sub-arctic area undergoing rapid land-use change. Bird Study 61:544-552.

Jónsson, J. E., A. Gardarsson, J. A. Gill, U. K. Pétursdóttir, A. Petersen, and T. G. Gunnarsson. 2013. Relationships between long-term demography and weather in a sub-arctic population of common eider. PloS one 8:e67093.

Katrínardóttir, B., J. A. Alves, H. Sigurjónsdóttir, P. Hersteinsson, and T. G. Gunnarsson. 2015. The Effects of Habitat Type and Volcanic Eruptions on the Breeding Demography of Icelandic Whimbrels Numenius phaeopus. PloS one 10:e0131395.

Liebezeit, J. R., P. A. Smith, R. B. Lanctot, H. Schekkerman, I. Tulp, S. J. Kendall, D. M. Tracy, R. J. Rodrigues, H. Meltofte, and J. A. Robinson. 2007. Assessing the development of shorebird eggs using the flotation method: species-specific and generalized regression models. The Condor 109:32-47.

Marske, K. A., M. A. Ivie, and G. M. Hilton. 2007. Effects of volcanic ash on the forest canopy insects of Montserrat, West Indies. Environmental entomology 36:817-825.

Pearce-Higgins, J. W., P. Dennis, M. J. Whittingham, and D. W. Yalden. 2010. Impacts of climate on prey abundance account for fluctuations in a population of a northern wader at the southern edge of its range. Global Change Biology 16:12-23.

Petersen, G., H. Bjornsson, P. Arason, and S. v. Löwis. 2012. Two weather radar time series of the altitude of the volcanic plume during the May 2011 eruption of Grímsvötn, Iceland. Earth System Science Data 4:121-127.

$R$ Development Core Team. 2008. R: A language and environment for statistical computing. $R$ Foundation for Statistical Computing, Vienna, Austria.

Robinson, R. A., C. A. Morrison, and S. R. Baillie. 2014. Integrating demographic data: towards a framework for monitoring wildlife populations at large spatial scales. Methods in Ecology and Evolution 5:1361-1372.

Schekkerman, H., M. Van Roomen, and L. Underhill. 1998. Growth, behaviour of broods and weather-related variation in breeding productivity of Curlew Sandpipers Calidris ferruginea. Ardea 86:153-168.

Senner, N. R., M. A. Verhoeven, J. M. Abad-Gómez, J. S. Gutierrez, J. C. Hooijmeijer, R. Kentie, J. A. Masero, T. L. Tibbitts, and T. Piersma. 2015. When Siberia came to the Netherlands: the response of continental black-tailed godwits to a rare spring weather event. Journal of Animal Ecology 84:1164-1176.

Sigmundsson, F., S. Hreinsdóttir, A. Hooper, T. Árnadóttir, R. Pedersen, M. J. Roberts, N. Óskarsson, A. Auriac, J. Decriem, and P. Einarsson. 2010. Intrusion triggering of the 2010 Eyjafjallajokull explosive eruption. Nature 468:426-430.

Stewart, C., D. Johnston, G. Leonard, C. Horwell, T. Thordarson, and S. Cronin. 2006. Contamination of water supplies by volcanic ashfall: a literature review and simple impact modelling. Journal of Volcanology and Geothermal Research 158:296-306.

Stojanovic, D., M. H. Webb, R. Alderman, L. L. Porfirio, and R. Heinsohn. 2014. Discovery of a novel predator reveals extreme but highly variable mortality for an endangered migratory bird. Diversity and Distributions 20:1200-1207.

Summers, R. W., and L. G. Underhill. 1987. Factors related to breeding production of Brent Geese Branta b. bernicla and waders (Charadrii) on the Taimyr Peninsula. Bird Study 34:161-171.

This article is protected by copyright. All rights reserved. 
Sutherland, W. J., J. A. Alves, T. Amano, C. H. Chang, N. C. Davidson, C. Max Finlayson, J. A. Gill, R. E. Gill, P. M. González, and T. G. Gunnarsson. 2012. A horizon scanning assessment of current and potential future threats to migratory shorebirds. Ibis 154:663-679.

Sæther, B.-E., V. Grøtan, S. Engen, T. Coulson, P. R. Grant, M. E. Visser, J. E. Brommer, B. R. Grant, L. Gustafsson, and B. J. Hatchwell. 2016. Demographic routes to variability and regulation in bird populations. Nature Communications 7: 12001.

Thomas, G., R. Lanctot, and T. Szekely. 2007. Population declines in North American shorebirds: ecology, life-history and sexual selection. In: Boere, G. C., Galbraith, C. A. and Stroud, D. A., eds. Waterbirds around the World. Edinburgh: The Stationery Office, pp. 207-208.

Tulp, I., and H. Schekkerman. 2008. Has prey availability for arctic birds advanced with climate change? Hindcasting the abundance of tundra arthropods using weather and seasonal variation. Arctic $61: 48-60$.

This article is protected by copyright. All rights reserved. 
Figure 1. Map of Iceland and the location of the 198-km road transect along which Godwit broods were surveyed in late June 2011-2016.
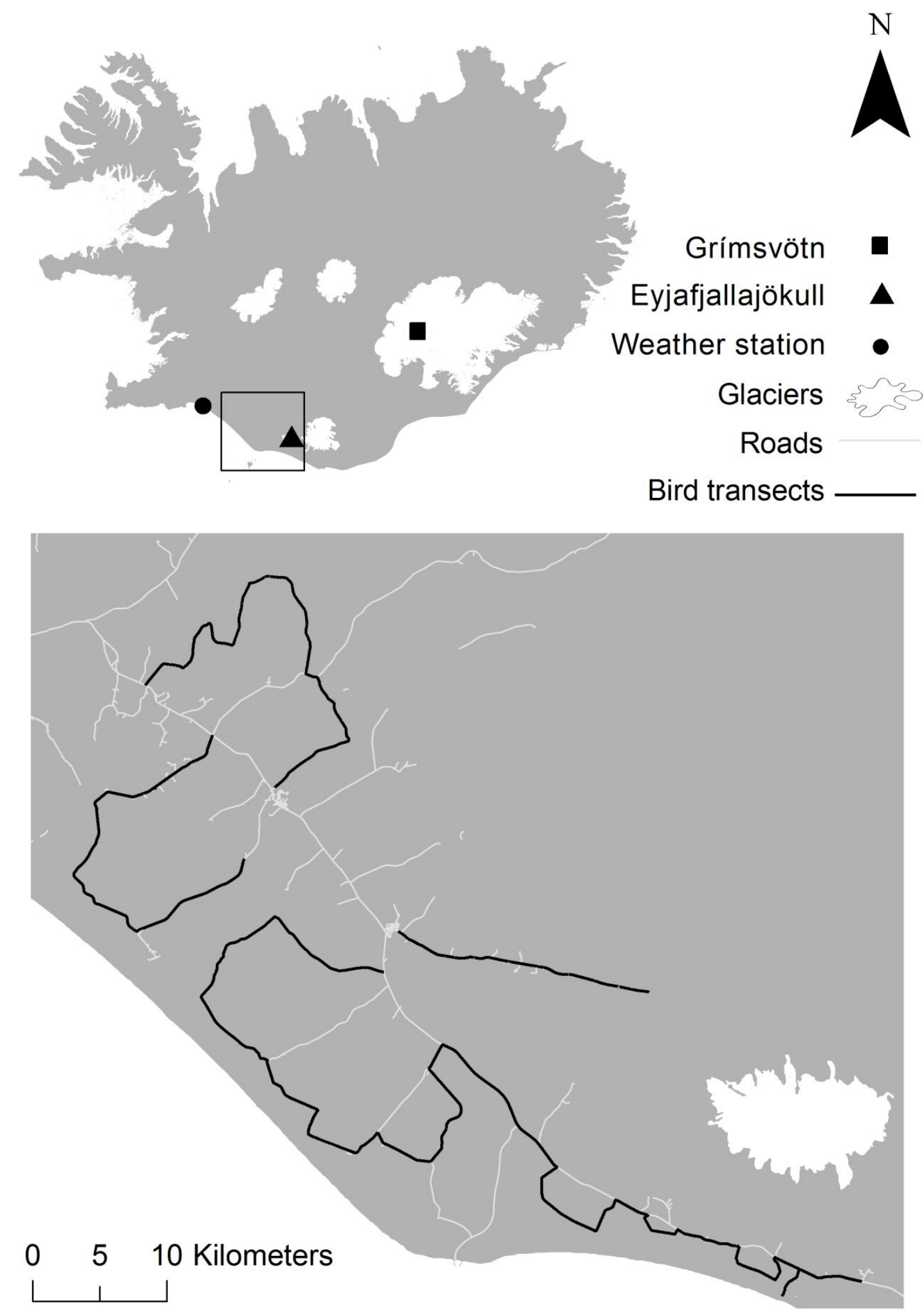

This article is protected by copyright. All rights reserved. 
Figure 2. (a) Annual variation in productivity of Black-tailed Godwits and (b) the relationship between mean May temperature and large-scale productivity. Productivity is measured as the number of broods recorded along a fixed road transect in Southern Iceland each year. The line is fitted through years 2012-2016 but 2011, which was the only year with a volcanic eruption, is shown by an open circle. Linear model without eruption year: $R^{2}=0.94, P=0.007$; Linear model including eruption year: $R^{2}=0.11, P=0.53$ ).

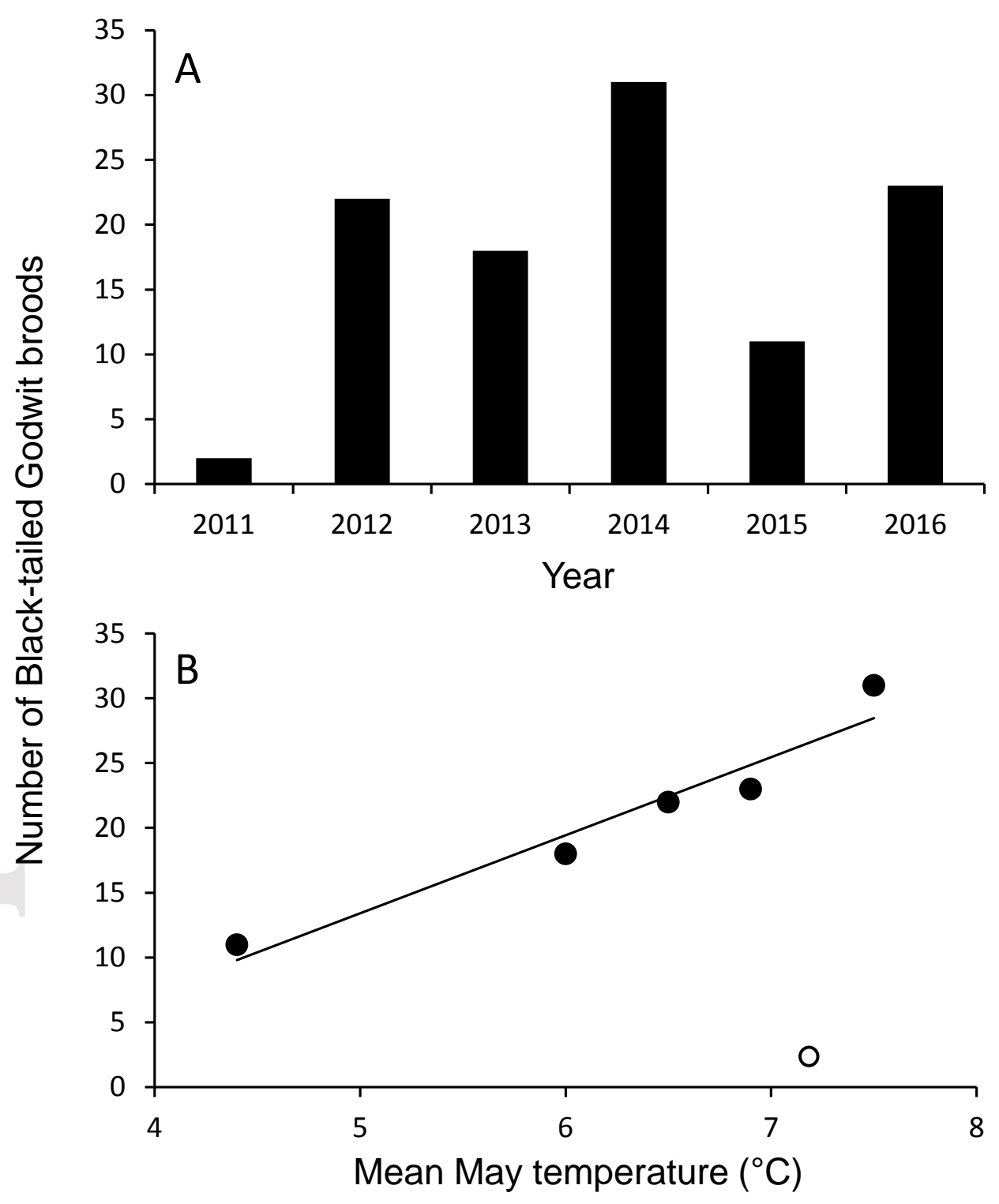

This article is protected by copyright. All rights reserved. 